announced; the countries and the number of awards are as follows : Austria (3), Belgium (8), Denmark (3), Finland (1), France (4), Germany (4), Italy (3), The Netherlands (6), Norway (4), Persia (1), Spain (1), Sweden (4) and Switzerland (1). Awards by the Government of Brazil will be announced shortly. These scholarships by foreign countries correspond to those awarded by the British Council to foreign graduates for studying at universities in the United Kingdom. Further details about these schemes can be obtained from the British Council, 65 Davies Street, London, W.1.

\section{Sectional Meeting in New Delhi of the World Power Conference}

THE second post-war sectional meeting of the World Power Conference will be held in New Delhi during January 10-15, 1951. At the same time, the World Power Conference International Commission on Large Dams will hold its fourth congress, and the International Commission on Irrigation and Canals its first plenary session. During January-February an Indian international engineering exhibition will be open in New Delhi. The theme of the sectional meeting is the "Utilization of Power in its Various Aspects", and this will be considered under two headings : utilization of electricity in agriculture; and the coordination of the development of industries and the development of power resources. A set of three study tours (and an alternative set) which between them cover most of the territory of India has been arranged, and on the completion of these tours the closing session of the conference and congress will be in Mysore on February 1. Details of these events are contained in Bulletin No. 2, issued by the Indian National Committee of the World Power Conference. This Bulletin can be obtained from the Secretary, Central Board of Irrigation, Curzon Road Barracks, New Delhi, or from the British National Committee, World Power Conference, 201 Grand Buildings, Trafalgar Square, London, W.C.2.

\section{Royal Society of Edinburgh : Officers for 1950-51}

Ar the annual statutory meeting of the Royal Society of Edinburgh, held on October 23, 1950, the following officers and members of council were elected : President, Prof. James Kendall ; VicePresidents, Prof. A. C. Aitken, Prof. E. P. Cathcart, Sir Alexander Gray, Prof. Arthur Holmes, Prof. W. O. Kermack and Prof. E. T. Copson; General Secretary, Dr. J. E. Richey; Secretaries to Ordinary Meetings, Prof. J. Norman Davidson and Dr. John E. MacKenzie; Treasurer, Mr. A. W. Young; Curator of Library and Museum, Dr. Douglas Guthrie; Councillors, Mr. E. G. Dymond, Prof. R. W. Wheldon, Prof. T. Neville George, Prof. J. W. Heslop Harrison, Dr. C. E. Lucas, Prof. M. G. Say, Prof. W. M. Smart, Prof. J. F. Allen, Prof. A. Murray Drennan, Dr. E. Wyllie Fenton, Mr. J. M. Ross and Prof. C. M. Yonge.

\section{The Night Sky in November}

New moon occurs on Nov. 9d. 23h. 25m., U.T., and full moon on Nov. 24d. 15h. 14m. The following conjunctions with the moon take place : Nov. 6d. 19h., Saturn $2^{\circ} \mathrm{N}$.; Nov. 13d. 04h., Mars $4^{\circ} \mathrm{N}$.; Nov. 16d. 23h., Jupiter $1^{\circ} \mathrm{N}$. Mercury, in superior conjunction on November 1 , is too close to the sun for favourable observation during the month. Venus, in superior conjunction on November 13, is unfavourably placed for observation during most of the month. Mars is an evening star and sets more than two hours after the sun during November; its declination is more than $24^{\circ} \mathrm{S}$. and, as it lies rather low even at meridian passage in the British Isles, it is not well placed for observation. Jupiter, in the constellation of Aquarius, sets at $0 \mathrm{~h} .10 \mathrm{~m} ., 23 \mathrm{~h} .20 \mathrm{~m}$. and $22 \mathrm{~h} .30 \mathrm{~m}$. on November 1,15 and 30 , respectively, and is well placed for observation. Saturn, in the constellation of Virgo, is a morning star, rising at $3 \mathrm{~h}$., $2 \mathrm{~h} .15 \mathrm{~m}$. and $1 \mathrm{~h} .25 \mathrm{~m}$. at the beginning, middle and end of the month, respectively. Occultations of stars brighter than magnitude 6 are as follows: Nov. 6d. 4h. 47.6m., 89 Leon. $(R)$; Nov. 20d. $20 \mathrm{~h}$. $46 \cdot 0 \mathrm{~m} .$, $\varepsilon$ Pisc. $(D)$; Nov. 26d. 18h. 23.3m., 136 Taur. $(D)$; Nov. 26 d. $19 \mathrm{~h} .05 \cdot 2 \mathrm{~m} ., 136$ Taur. $(R)$; Nov. 30 d. 0 h. $39 \cdot 0 \mathrm{~m}$., $\gamma$ Canc. $(R), \quad R$ and $D$ refer to reappearance and disappearance, respectively, and the latitude of Greenwich is assumed.

\section{Announcements}

SIR LEwIS Fermor has been elected president for the session 1951-52 of the Institution of Mining and Metallurgy. Sir Lewis served with the Geological Survey of India from 1902 until his retirement as director in 1935. He has since been engaged in consulting work in India, Malaya and Africa.

The Council of the Royal Society of Edinburgh has awarded the David Anderson-Berry Prize for 1950, posthumously, to Dr. D. E. Lea, for his book "The Actions of Radiations on Living Cells".

THE Melchett Medal for 1950 of the Institute of Fuel has been awarded to Prof. R. J. Sarjant, professor of fuel technology in the University of Sheffield. The Medal was established and endowed by the founder-president of the Institute, the late Lord Melchett of Landford, and is awarded from time to time for outstanding work in research, administration, construction or any other professional activity involving the scientific preparation or use of fuel. There have to date been six overseas recipients, and Prof. Sarjant is the fourteenth British holder of the award.

Mr. G. M. Mrchie has joined the Research and Development Division of the British Steel Founders' Association in a senior executive capacity. Mr. Michie, who for the past two years has been senior research metallurgist in charge of the research laboratories at Penistone of Messrs. David Brown and Sons (Huddersfield), Ltd., is known for his work on the development and application of non-destructive testing of steel castings.

THE Institution of Naval Architects has made the following awards: Froude Research Scholarship in Naval Architecture (1950), of $£ 500$ a year for two years, to R. L. Townsin, of King's College, Newcastle upon Tyne; Sir William White Postgraduate Scholarship in Naval Architecture (1948), of $£ 150$ a year, to D. I. Moor, of Messrs. William Denny and Bros., Dumbarton, for one further year ; Parsons Scholarship in Marine Engineering (1950), of $£ 175$ a year, to G. M. Jordan, of Messrs. Alfred Holt and Co., Liverpool, for three years at the University of Liverpool ; Yarrow Scholarship in Marine Engineering (1950), of $£ 175$ a year, to A. W. Bolwell, of Messrs. Yarrow and Co., Scotstoun, Glasgow, for four years at the University of Glasgow. 